\title{
PENERAPAN MODEL PEMBELAJARAN KOOPERATIF TIPE NUMBERED HEADS TOGETHER (NHT) UNTUK MENINGKATKAN HASIL BELAJAR SISWA PADA MATERI PERSAMAAN KUADRAT KELAS X IPA A SMA NEGERI 1 AMPIBABO
}

\author{
Elin Rostriana ${ }^{1)}$, Muh, Rizal ${ }^{2)}$, Bakri Mallo ${ }^{3)}$ \\ elintriana188@gmail.com ${ }^{1)}$, rizaltberu97@yahoo.com ${ }^{2)}$,bakri88oke@gmail.com ${ }^{3)}$
}

\begin{abstract}
Abstrak: Tujuan penelitian ini adalah untuk memperoleh deskripsi tentang penerapan model pembelajaran kooperatif tipe Numbered Heads Together (NHT) yang dapat meningkatkan hasil belajar siswa pada Materi Persamaan Kuadrat Kelas $X$ IPA A SMA Negeri 1 Ampibabo. Jenis penelitian yang digunakan adalah penelitian tindakan kelas (PTK) yang mengacu pada desain penelitian Kemmis dan Mc. Taggart. Hasil penelitian menunjukan bahwa penerapan model pembelajaran kooperatif tipe NHT yang dapat meningkatkan hasil belajar siswa pada materi persamaan kuadrat di kelas X IPA A SMA Negeri 1 Ampibabo, dengan mengikuti fase-fase sebagai berikut: (1) penomoran, (2) mengajukan pertanyaan atau permasalahan, (3) berpikir bersama, dan (4) menjawab.
\end{abstract}

Kata kunci: Numbered Heads Together, hasil belajar, persamaan kuadrat.

\begin{abstract}
Abstrack: The purpose of this study is to obtain a description of the application of cooperative learning model type Numbered Heads Together (NHT) that can improve student learning outcomes in the Material Equation Square X Class IPA A SMA Negeri 1 Ampibabo. The type of research used is classroom action research (PTK) which refers to the design research of Kemmis and Mc. Taggart. Based on these results, it can be concluded that the application of NHT type cooperative learning model that can improve student learning outcomes on the matter of quadratic equations in class X IPA A SMA! Ampibabo, by following the following phases: (1) numbering, (2) asking questions or problems, (3) ask students to study, and (4) answered.
\end{abstract}

Keywords: Type Numbered Heads Together, Learning Outcomes, Persamaan Kuadrat

Matematika merupakan salah satu mata pelajaran yang dipelajari mulai dari sekolah dasar hingga perguruan tinggi dengan tujuan untuk membekali mereka dengan kemampuan berpikir logis, analitis, sistematis, kritis dan kreatif sejak dini. Walaupun mata pelajaran ini dipelajari sejak SD, tetapi masih tetap dianggap sulit oleh para siswa. Tidaklah heran bila banyak dijumpai di sekolah-sekolah pengusaan siswa terhadap materi matematika masih tergolong rendah bila dibandingkan dengan mata pelajaran yang lain.

Kondisi seperti itu terjadi pula pada SMA Negeri 1 Ampibabo. Hasil wawancara dengan guru diperoleh informasi bahwa siswa di sekolah tersebut masih sulit dalam menyelesaikan soal persamaan kuadrat khususnya dengan menggunakan pemfaktoran dan melengkapkan kuadrat sempurna.

Faktor yang menyebabkan rendahnya hasil belajar siswa pada materi persamaan kuadrat khususnya dengan cara pemfaktoran dan cara melengkapkan bentuk kuadrat sempurna adalah masih banyak siswa yang mengalami kesulitan dalam menyelesaikan soal kerena siswa kurang memahami konsep, rasa ingin tahu siswa yang sangat kurang, dan tidak adanya rasa percaya diri kerena selalu menganggap dirinya kurang mampu. Dalam menentukan nilai $p$ dan $q$ siswa lebih cenderung mencoba-coba sehingga sering terjadi kesalahan dalam menyelesaikan soal tersebut, siswa juga kurang aktif dalam proses belajar mengajar sehingga siswa tidak menayakan hal-hal yang kurang dipahami. 
Guna memperoleh informasi yang lebih jelas sebagai tindaklanjut dari hasil wawancara dengan guru mata pelajaran matematika kelas X SMA Negeri 1 Ampibabo peneliti memberikan tes mengenai materi persamaan kuadrat khususnya dengan cara pemfaktoran dan cara melengkapkan bentuk kuadrat sempurna di kelas XI IPA $A_{1}$ yang telah mempelajari materi persamaan kuadrat dan diajarkan oleh guru yang sama.

Adapun soal yang diberikan yaitu : 1) Tentukan akar-akar penyelesaian dari persamaan kuadrat berikut dengan bentuk faktorisasi: (a) $x^{2}-2 \mathrm{x}+1=0$, (b $2 x^{2}+4 \mathrm{x}-6=0$. 2) Tentukan akar-akar penyelesaian dari persamaan kuadrat berikut dengan cara melengkapkan bentuk kuadrat sempurna: (a) $x^{2}+2 \mathrm{x}+1=0$, (b) $2 x^{2}-4 \mathrm{x}+2=0$.

Berdasarkan tes identifikasi kepada 35 orang siswa maka jawaban siswa dikelompokkan dalam beberapa kelompok jawaban sesuai dengan kesalahan yang dilakukan di masing-masing soal, yaitu sebagai berikut:

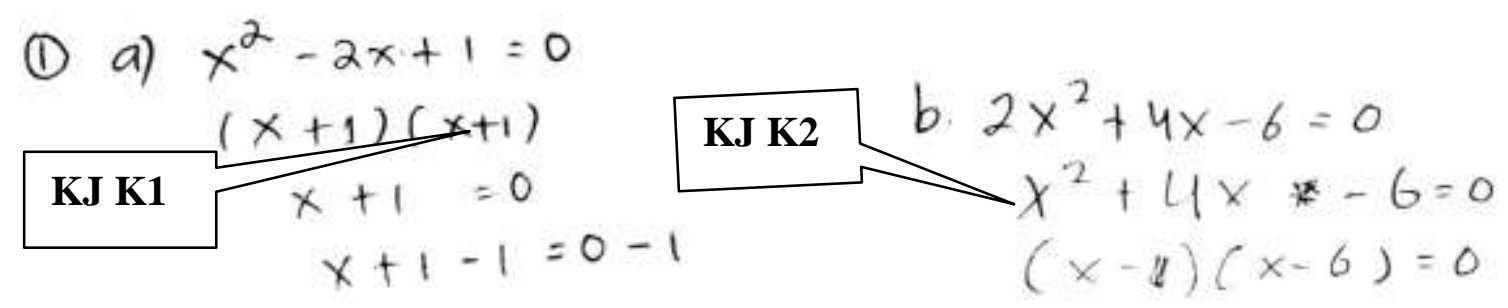

Gambar 1. Kelompok jawaban soal no 1a

Gambar 2. Kelompok jawaban soal no 1b

$$
\begin{aligned}
& x^{2}+2 x+1=0 \\
& (x+1)(x+1)=0 \\
& x+1=0 \\
& x=-1
\end{aligned} \quad \begin{aligned}
x+1=0 \\
\text { KJ K3 }
\end{aligned} \quad \begin{aligned}
x+1 & =0-1 \\
x & =-1
\end{aligned}
$$

Gambar 3. Kelompok jawaban soal no 2a

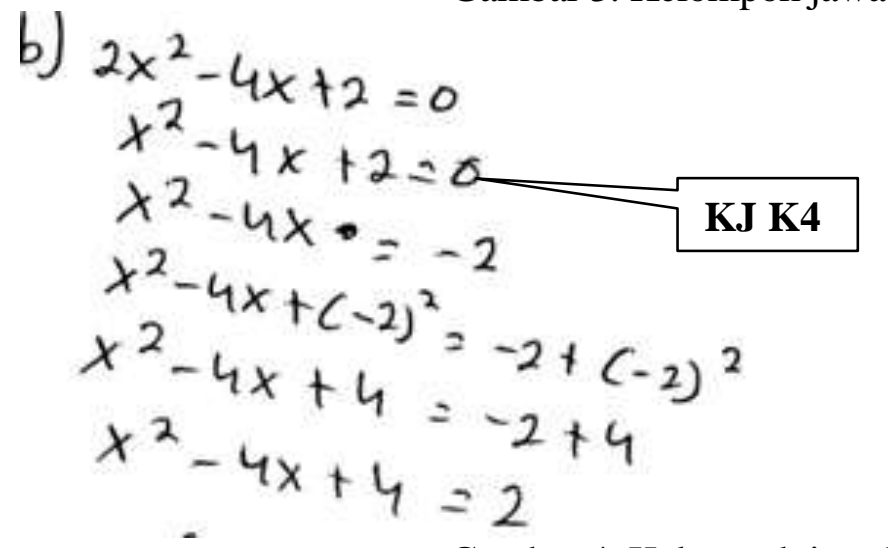

$$
\begin{aligned}
(x+4)^{2} & =2 \\
(x+4)^{2} \frac{1}{2} & =2^{1}-\frac{1}{2} \\
(x+4)^{1} & =2^{1 / 2} \\
x+4 & =1 \\
x & =1-4 \\
x & =-3
\end{aligned}
$$

Gambar 4. Kelompok jawaban soal no 2b

Adapun analisis kesalahan yang diperoleh dari kelompok jawaban soal no 1a yaitu siswa sudah dapat menentukan koefisien $c$ hanya saja siswa tidak menyesuaikan dengan koefisien $b$ yang mana jika bilangan tersebut dijumlahkan tidak menghasilkan koefisien $b$ ( KJ K1 ). Analisis kesalahan yang diperoleh dari kelompok jawaban soal no $1 \mathrm{~b}$ yaitu siswa hanya membuat koefisien $x^{2}$ menghasilkan bilangan 1 akibatnya siswa kebingungan dalam mencari nilai $p$ dan $q$ dan siswa tidak biasa mengerjakan soal dengan benar ( KJ K2 ). Sedangkan Analisis kesalahan yang diperoleh dari jawaban kelompok jawaban soal no 2a yaitu siswa tidak 
mengerjakan soal sesuai dengan perintah soal melainkan siswa mengerjakan soal dengan cara pemfaktoran, yang berarti siswa belum mengerti cara mengerjakan soal persamaan kuadrat dengan cara melengkapkan bentuk kuadrat sempurna ( KJ K3 ). Analisis kesalahan yang diperoleh dari jawaban kelompok jawaban soal no $2 \mathrm{~b}$ yaitu siswa tidak mengerti cara mengerjakan soal dengan cara melengkapkan bentuk kuadrat sempurna, seharusnya bukan hanya koefisien dari $x^{2}$ yang disederhanakan menjadi bilangan 1 tetapi semua ruas baik ruas kanan maupun ruas kiri ( KJ K4 ).

Informasi lain yang diperoleh dari guru matematika bahwa dalam proses belajar mengajar masih didominasi oleh siswa yang pandai, sehingga ketika siswa yang lain mengalami kesulitan atau kurang memahami materi yang diajarkan, siswa takut untuk menanyakan dan meminta penjelasan kepada guru yang bersangkutan, siswa juga malas dalam berlatih untuk mengerjakan soal-soal jika guru tidak memberikan tugas rumah sehingga minat untuk belajar siswa kurang.

Berdasarkan permasalahan yang diperoleh, maka diperlukan pembelajaran yang dapat meningkatkan aktivitas siswa dalam pembelajaran sehingga dapat mengurangi kesalahan yang dilakukan siswa dalam mengerjakan soal-soal yang diberikan dan diharapkan dapat meningkatkan hasil belajar siswa. Salah satu alternatif pembelajaran yang menurut peneliti dapat mengantisipasi kurangnya aktivitas siswa dalam proses belajar mengajar dan dapat meningkatkan hasil belajar siswa adalah dengan menerapkan model pembelajaran kooperatif tipe Numbered Heads Together (NHT).

Adapun beberapa hasil penelitian yang menunjukan bahwa penerapan model pembelajaran kooperatif tipe Numbered Heads Together (NHT) dalam pembelajaran matematika merupakan alternatif yang baik dalam upaya meningkatkan hasil belajar siswa adalah penelitian yang dilakukan Elsa Febriasari (2016) yang menyimpulkan bahwa penerapan model pembelajaran tipe NHT dapat meningkatkan hasil belajar siswa pada materi pemfaktoran bentuk aljabar di kelas VIII A SMP Negari 1 Taopa. Selanjutnya, Suhardi (2014) yang menyimpulkan penerapan model pembelajaran tipe NHT dapat meningkatkan hasil belajar IPA kelas IV SD Negeri 3 Tondo. Selanjutnya, Juliah (2013) yang menyimpulkan penerapan model pembelajaran tipe NHT dapat meningkatkan hasil belajar siswa pada materi persamaan kuadrat di kelas X B MA Negeri Tomini, dan dapat membuat siswa aktif dalam kegiatan pembelajaran.

\section{METODE PENELITIAN}

Jenis penelitian yang digunakan adalah penelitian tindakan kelas (PTK) yang mengacu pada model penelitian kelas yang dikembangkan oleh Kemmis dan Mc Taggart Arikunto (2007:16) yang terdiri atas empat komponen, yaitu perencanaan (planning), tindakan (acting), pengamatan (observing), dan refleksi (reflecting). Subjek penelitian ini adalah seluruh siswa kelas X IPA A SMA Negeri 1 Ampibabo yang berjumlah 38 orang yang terdiri dari 13 laki-laki dan 25 perempuan yang terdaftar pada tahun ajaran 2016/2017. Pada penelitian ini juga akan dipilih 3 orang informan untuk keperluan wawancara dengan kualifikasi kemampuan yang berbeda (berkemampuan tinggi, sedang, dan rendah).

Teknik pengumpulan data adalah data aktivitas guru dan data aktivitas siswa yang diambil dengan menggunakan lembar observasi aktivitas guru dan aktivitas siswa, catatan lapangan, data penguasaan siswa terhadap materi yang diambil dengan menggunakan teknik wawancara, serta tes tertulis yang berupa tes awal dan tes akhir tindakan yang diambil dengan pemberian tes.

Analisis data dilakukan mengacu pada analisis data kualitatif model Miles dan Huberman dalam Sugiyono (2014:404-412), yaitu 1) Data Reduction (reduksi data), 2) Data Display 
(penyajian Data), 3) Conclusion Drawing/Verification (penarikan kesimpulan). Penelitian ini dilakukan sebanyak 2 siklus yaitu siklus I dan siklus II. Tindakan pembelajaran dalam penelitian ini dikatakan berhasil apabila siswa memahami materi persamaan kuadrat khususnya dengan cara pemfaktoran dan cara melengkapkan bentuk kuadrat sempurna. Hal ini dapat diketahui jika siswa (informan) mampu menyelesaikan masalah persamaan kuadrat khususnya dengan cara pemfaktoran dan cara melengkapkan bentuk kuadrat sempurna. Siswa dikatakan mampu apabila telah memenuhi indikator keberhasilan penelitian pada siklus I dan siklus II yang diperoleh dari tes akhir tindakan. Indikator keberhasilan penelitian ini diperkuat dengan melihat nilai ketuntasan individu dan persentase ketuntasan belajar klasikal siswa. Selain itu, keberhasilan tindakan juga dilihat pada hasil pengamatan aktivitas guru (peneliti) dan siswa selama proses pembelajaran berlangsung dengan hasil pengamatan pada setiap indikator yang diamati berkategori baik atau sangan baik.

\section{HASIL PENELITIAN}

Penelitian ini terdiri dari dua tahap yaitu tahap pra tindakan dan tahap pelaksanaan tindakan. Pada tahap pra tindakan peneliti memberikan tes awal yang bertujuan untuk mengetahui kemampuan awal siswa dan hasilnya dijadikan pedoman untuk membagi siswa dalam kelompok belajar yang heterogen, serta untuk menentukan informan yang dalam kategori rendah, sedang, dan tinggi. Setelah memberikan tes awal peneliti dan guru matematika tersebut memeriksa dan menganilisis hasil pekerjaan siswa. Dari hasil analisis tes awal (lampiran 3) diperoleh bahwa siswa yang menjawab soal dengan benar berjumlah 17 siswa, dan siswa yang menjawab soal dengan salah berjumlah 21 siswa dengan ketuntasan belajar klasikal sebesar 44,73 \%. Hal ini memberikan gambaran bahwa hasil belajar siswa terhadap materi prasyarat masih sangat rendah.

Pelaksanaan tindakan dalam penelitian ini terdiri dari dua siklus yaitu siklus 1 dan siklus 2. Setiap siklus dilakukan dalam satu kali pertemuan. Pelaksanaan pembelajaran dilakukan dalam tiga tahap, yaitu (1) kegiatan pendahuluan, (2) kegiatan inti, dan (3) kegiatan penutup.

Pelaksanaan tindakan siklus 1 dan siklus 2 dimulai dengan kegiatan pendahuluan yaitu peneliti memulai kegiatan awal pembelajaran dengan memberikan salam dan mengajak siswa untuk berdoa sebelum belajar yang dipimpin oleh ketua kelas dan mengecek kehadiran siswa. Kemudian peneliti menyampaikan tujuan pembelajaran yang akan dicapai pada siklus I yaitu diberikan suatu persamaan kuadrat yang ditentukan, sehingga siswa dapat menyelesaikan persamaan kuadrat dengan cara pemfaktoran, sedangkan pada siklus II yaitu diberikan suatu persamaan kuadrat yang ditentukan, sehingga siswa dapat menyelesaikan persamaan kuadrat dengan cara melengkapkan bentuk kuadrat sempurna. Peneliti selanjutnya menjelaskan secara singkat tentang model pembelajaran kooperatif tipe NHT yang diterapkan dalam pembelajaran. Setelah itu, peneliti memotivasi siswa untuk bersemangat dan terlibat aktif dalam pembelajaran serta memberi penjelasan bahwa sangat penting mempelajari materi persamaan kuadrat kerena matari juga ada pada ujian semester nanti dan merupakan matari ujian nasional nanti. Pada saat melakukan apersepsi guru melakukan tanya jawab dengan siswa.

Kegiatan inti dari setiap siklus dimulai dengan langkah penyajian informasi. Informasi yang diberikan pada siklus I yaitu materi menyelesaikan persamaan kuadrat dengan cara pemfaktoran sedangkan pada siklus II yaitu materi menyelesaikan persamaan kuadat dengan cara melengkapkan bentuk kuadrat sempurna. Selanjutnya peneliti menerapkan fase-fase model pembelajaran NHT yaitu fase penomoran, fase pengajuan pertanyaan/masalah, fase berpikir bersama, dan fase menjawab. 
Fase penomoran untuk siklus I dan siklus II guru membagikan siswa dalam 7 kelompok dan memberikan nama pada masing-masing kelompok yaitu Kelompok 1, Kelompok 2, Kelompok 3, Kelompok 4, Kelompok 5, Kelompok 6, dan Kelompok 7. Pada saat pelaksanaan terdapat 3 siswa yang tidak hadir sehingga masing-masing anggota kelompok memperoleh nomor $1,2,3,4$, dan 5 .

Fase mengajukan pertanyaan atau permasalahan untuk siklus I dan siklus II yaitu memberikan pertanyaan-pertanyaan yang termuat dalam lembar kerja siswa (LKS) kepada masing-masing kelompok. Terdapat 5 nomor soal yang termuat dalam LKS. Pertanyaanpertanyaan tersebut selanjutnya dibagi pada masing-masing anggota kelompok untuk dikerjakan, sehingga setiap anggota kelompok memiliki tugas dan tanggungjawab.

Fase berpikir bersama untuk siklus I dan siklus II, saat berpikir bersama siswa lebih bertanggungjawab terhadap tugas yang diberikan. Tanggungjawab tersebut ditandai dengan siswa mengerjakan tugas mereka masing-masing, siswa bertanya dengan teman atau guru ketika mengalami kesulitan dalam mengerjakan tugas dan siswa dalam kelompok saling mengajarkan apa-apa yang belum dimengerti dalam LKS.

Fase menjawab untuk siklus I dan siklus II, peneliti melakukan pengundian untuk menentukan siswa yang akan mempersentasikan hasil kerja kelompoknya secara acak untuk maju mempersentasikan jawabannya, sedangkan siswa yang bernomor sama dari kelompok lain akan menanggapi. Pengundian dilakukan dengan mengambil gulungan kertas yang guru buat sebelumnya. Pada siklus I dimulai dari guru dan akan dilanjutkan oleh siswa yang telah dipilih oleh guru dari hasil pengambilan gulungan sampai seterusnya, sedangkan untuk siklus II dilakukan bersamaan mengingat waktu yang akan molor seperti pada siklus I.

Kegiatan penutup untuk siklus I dan siklus II, guru memberikan penghargaan kepada kelompok yang kompak dan aktif serta kelompok yang anggotanya lebih dari satu kali maju mempresentasikan jawabanya di depan kelas. Guru juga memberikan pekerjaan rumah (PR) kepada siswa terkait dengan materi.

Pada tes akhir tindakan siklus 1, peneliti memberi 2 nomor soal. Berikut satu diantara soal yang diberikan kepada siswa yaitu tentukan akar-akar persamaan dari $2 x^{2}-2 x-4=0$. Salah satu jawaban siswa yang diperoleh yaitu jawaban siswa HD sebagai berikut.

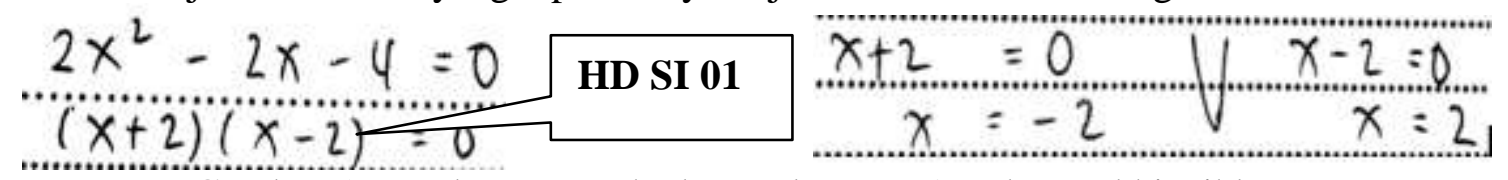

Gambar 5. Jawaban HD terhadap soal nomor 1 pada tes akhir siklus I

Hasil tes akhir tindakan siklus I menunjukkan bahwa umumnya siswa belum mengerti cara menyelesaikan soat tersebut. Hal ini ditunjukan dengan melihat hasil kerja HD yang pada dasarnya letak kesalahannya sama dengan siswa lainnya yaitu HD sudah mengerti menyelesaikan persamaan kuadrat dengan cara pemfaktoran hanya saja HD belum tepat dalam mencari bilangan yang jika dijumlahkan menghasilkan $\mathrm{b}$ dan jika dikalikan menghasilkan ac (HD SI 01). Adapun hasil wawancara yang peneliti lakukan dengan HD sebagaimana kutipan wawancara berikut.

HD S1 10 S: hehehe yang nomor 1 saya keliru kaka.

HD S1 11 P: hehehe kenapa bisa begitu?

HD S1 12 S: karena takut kehabisan waktu saya tidak sempat memeriksanya kembali, seharusnya jika difaktorkan menjadi $(2 \mathrm{x}+2)(\mathrm{x}-2)$ tapi saya lupa menuliskan bilangan 2 dan hanya menulis $\mathrm{x}+2$ sehingga akar-akar penyelesaiannya itu bukan -2 dan 2 tetapi -1 dan 2.

HD S1 13 P: selain difaktorkan menjadi $(2 x+2)(x-2)$, apakah ada cara lain yang adik bisa? 
HD S1 14 S: iya ada, semuanya dikalikan $\frac{1}{2}$ kak dan kemudian akan menjadi $x^{2}-x-2$ sehingga jika difaktorkan akan menjadi $(\mathrm{x}+1)(\mathrm{x}-2)$ dan akar-akar penyelesaiannya -1 dan 2 . HD S1 15 P: iya, jadi adik sudah mengerti bagaimana cara menyelesaikan soal nomor 1. HD S1 16 S: iya kak.

Pada tes akhir tindakan siklus II, peneliti memberi 2 nomor soal. Berikut satu diantara soal yang diberikan kepada siswa yaitu: Tentukan akar-akar persamaan dari $2 x^{2}-2 x-4=$ 0 . Salah satu jawaban siswa yang diperoleh yaitu jawaban siswa AT sebagaimana gambar berikut:

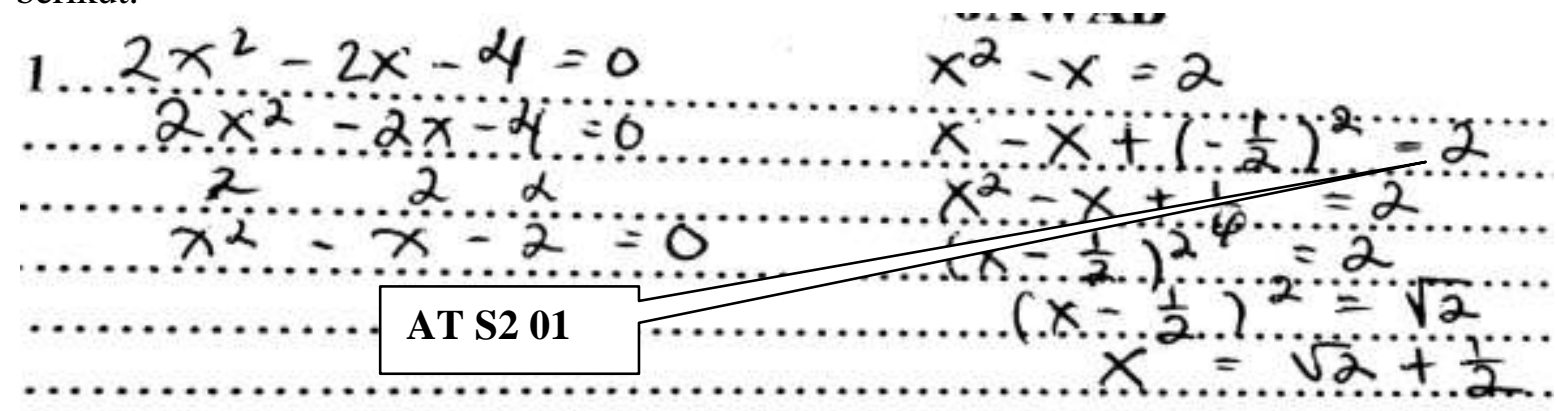

Gambar 6. Jawaban AT terhadap soal nomor 1 pada tes akhir siklus II

Hasil tes akhir tindakan siklus 2 menunjukkan bahwa umumnya siswa dapat menyelesaikan soal yang diberikan. Namun masih ada beberapa kesalahan yang dilakukan oleh siswa pada saat menyelesaikan soal yang diberikan. Satu diantara siswa tersebut adalah AT. Kesalahan yang terdapat pada jawaban AT yaitu AT tidak menambahkan kedua ruas dengan setengah nilai $\mathrm{x}$ dan dipangkat dua tetapi AT hanya melakukannya pada ruas kiri sehingga dalam pengoperasiannya tidak mendapatkan akar-akar penyelesaian yang benar (AT S2 01). Adapun hasil wawancara yang peneliti lakukan dengan HD sebagaimana kutipan wawancara berikut.

AT S2 10 S: iyaa, tau kaka. Nomor 1 seharusnya pada langkah menambahkan kadua ruas dengan setengah nilai x yaitu - $\frac{1}{2}$ bukan hanya ruas kanan yang di tambahkan tapi ruas kiri juga di tambahkan dengan - $\frac{1}{2}$ kemudian dioperasikan dan dilanjutkan dengan langkah-langkah berikut sehingga nilai akar-akar penyelesainnya bukan seperti yang saya kerjakan kaka.

AT S2 11 P: berarti adik sudah mengerti cara menyelesaikan soal persamaan kuadrat dengan cara melengkapkan bentuk kuadrat sempurna.

AT S2 12 S: iya sudah, saya hanya keliru di satu langkah saja kaka.

Aspek yang diobservasikan sesuai dalam lembar observasi aktivitas guru pada siklus I dan siklus II, meliputi: (1) mengorganisasikan siswa dalam kelompok belajar yang bersifat heterogen, sekaligus memberikan nama yang berbeda pada setiap kelompok, (2) memberikan nomor kepada kelompok dan menjelaskan tanggung jawab siswa dalam kelompok, (3) memberikan bahan ajar dan lks kepada setiap kelompok, (4) mengarahkan dan membimbing siswa untuk mempelajari materi dan mengerjakan lks secara berkelompok, memberikan bantuan, mengontrol siswa dalam belajar kelompok, (5) mempersilakan siswa untuk bertanya jika ada siswa yang kesulitan dalam mengerjakan lks, (6) memanggil salah satu di antara nomor siswa secara acak dan mempersilakan siswa untuk mempresentasikan jawabannya di depan kelas untuk mengecek pemahaman siswa, dan (7) membantu siswa menyimpulkan hasil pembelajaran pada materi tersebut. 
Hasil observasi pengamat terhadap aktivitas guru pada siklus I yaitu aspek pada nomor 1, 2, dan 3 memperoleh skor 4 atau pada kategori sangat baik. Aspek pada nomor 4. 6, dan 7 memperoleh skor 3 atau pada kategori baik. Sedangkan aspek nomor 5 memperoleh skor 2 atau pada kategori kurang. diperoleh total skor penilaian adalah 23 yang artinya taraf aktivitas guru selama pembelajaran berada dalam kategori baik atau dalam persentase 67,64 \%. Sedangkan hasil observasi pengamat terhadap aktivitas guru pada siklus II yaitu aspek pada nomor 1, 2, 3, 6, dan 7 memperoleh skor 4 atau pada kategori sangat baik. Sedangkan aspek pada nomor 4 dan 5 memperoleh skor 3 atau pada kategori baik, diperoleh total skor penilaian adalah 26 yang artinya taraf aktivitas guru selama pembelajaran berada dalam kategori baik atau dalam persentase $76,47 \%$.

Aspek yang diobservasikan sesuai dalam lembar observasi aktivitas siswa pada siklus I dan siklus II, meliputi: (1) Siswa duduk berdasarkan kelompok dan sesuai nomor yang telah ditentukan, (2) Siswa mendengarkan dan mengigat nomor yang diberikan guru, (3) Siswa menerima bahan ajar, LKS dan memperhatikan penjelasan guru, (4) Berdiskusi dalam kelompok untuk memikirkan jawaban dari pertanyaan yang diberikan guru, (5) Bertanya kepada guru jika mengalami kesulitan dalam belajar kelompok dan mengerjakan LKS, (6) Siswa yang disebut nomornya mempresentasikan jawabannya di depan kelas, dan (7) Menyimpulkan hasil pembelajaran.

Hasil observasi pengamat terhadap aktivitas siswa pada siklus I yaitu aspek pada nomor 3 dan 7 memperoleh skor 4 atau pada kategori sangat baik. Sedangkan aspek pada nomor 1,2,4,5, dan 6 memperoleh skor 3 atau pada kategori baik, diperoleh total skor penilaian adalah 23 yang artinya taraf aktivitas guru selama pembelajaran berada dalam kategori baik atau dalam persentase $67,64 \%$. Sedangkan hasil observasi pengamat terhadap aktivitas siswa pada siklus II yaitu aspek pada nomor 2, 3, dan 7 memperoleh skor 4 atau pada kategori sangat baik. Sedangkan aspek pada nomor 1, 4, 5, dan 6 memperoleh skor 3 atau pada kategori baik, diperoleh total skor penilaian adalah 24 yang artinya taraf aktivitas guru selama pembelajaran berada dalam kategori baik atau dalam persentase $70,58 \%$.

\section{PEMBAHASAN}

Sebelum pelaksanaan tindakan, peneliti terlebih dahulu memberikan tes awal untuk mengetahui kemampuan siswa pada materi prasyarat dan sebagai pedoman dalam pembentukan kelompok serta menentukan informan. Hal ini sesuai dengan pendapat paembonan (2014) menyatakan bahwa pelaksanaan tes awal bertujuan untuk mengetahui kemampuan awal siswa tentang materi prasyarat dan sebagai pedoman dalam pembentukan kelmpok belajar yang heterogen serta penentuan informan.

Pelaksanaan pembelajaran siklus I dan siklus II, peneliti mengikuti langkah-langkah pembelajaran menurut Suprijono (2009) yaitu kegiatan pendahuluan, kegiatan inti, dan kegiatan penutup. Peneliti juga menerapkan fase-fase pembelajaran kooperatif tipe NHT menurut Arends pada setiap pertemuan, yaitu : 1) fase penomoran, 2) fase mengajukan pertanyaan atau permasalahan, 3) fase berpikir bersama, dan 4) fase menjawab.

Menyampaikan tujuan dan memotivasi siswa, peneliti menyampaikan tujuan pembelajaran yang ingin dicapai dengan menuliskan di papan tulis agar siswa dapat mengetahui poin-poin dalam tujuan kegiatan pembelajaran sehingga siswa terarah dalam belajar. Hal ini sejalan dengan pendapat Prawiradilaga (2009) menyatakan bahwa menyampaikan tujuan pembelajaran atau kompetensi yang akan mereka peroleh dari penyajian materi nanti sangat diperlukan siswa karena mereka akan belajar terarah. Kemudian peneliti memotivasi siswa untuk bersemangat dalam pembelajaran dengan menyampaikan manfaat 
mempelajari materi persamaan kuadrat. Hal ini sejalan dengan pendapat Wijayanti (2010) menyatakan bahwa satu di antara cara guru membangkitkan motivasi belajar siswa adalah dengan menyampaikan manfaat dari materi yang dipelajari. Setelah itu, peneliti melakukan apersepsi untuk mengingatkan kembali pengetahuan prasyarat siswa dengan memberikan penjelasan singkat dan melakukan tanya jawab mengenai materi prasyarat. Hal ini sesuai dengan pendapat Hujono (Paembonan, 2014:76) menyatakan bahwa sebelum mempelajari konsep B, sseorang perlu memahami lebih dulu konsep A yang mendasari konsep B. Sebab tampa memahami konsep A, tidak mungkin orang itu memahami konsep B.

Menyajikan informasi, peneliti menyampaikan informasi tentang model pembelajaran yang digunakan, yaitu model pembelajaran kooperatif tipe NHT dan langkah-langkah yang harus dilakukan siswa nantinya agar siswa tidak bingung dengan model pembelajaran yang digunakan. Hal ini sesuai dengan pendapat Marno dan Idris (2009) bahwa pada awal pembelajaran, guru perlu memberikan petunjuk tentang langkah-langkah kegiatan secara jelas dan terarah. Materi pada siklus I, yaitu menyelesaikan persamaan kuadrat dengan cara pemfaktoran sedangkan materi siklus II, yaitu menyelesaikan persamaan kuadrat dengan cara melengkapkan bentuk kuadrat sempurna.

Fase penomoran, Peneliti mengelompokkan siswa kedalam 7 kelompok belajar yang heterogen berdasarkan kemampuan awal siswa. Jumlah anggota kelompok terdiri atas 5 siswa dan setiap anggota diberi nomor 1 sampai 5. Hal ini sejalan dengan pendapat Silalahi (2012) menyatakan bahwa model pembelajaran kooperatif tipe NHT menempatkan siswa dalam kelompok yang heterogen dan diberi nomor.

Fase mengajukan pertanyaan atau permasalahan, peneliti membagikan LKS pada setiap kelompok. Terdapat 5 pertanyaan yang berbeda yang dibagi pada masing-masing anggota kelompok. Setelah itu, peneliti menjelaskan tanggung jawab siswa dalam kelompok. Hal ini sejalan dengan pendapat Silalahi (2012) menyatakan bahwa siswa dalam kelompok diberi nomor kemudian secara acak guru memberikan tugas yang berbeda untuk setiap nomor.

Fase berpikir bersama, peneliti mengarahkan siswa untuk mempelajari materi pembelajaran terlebih dahulu sebelum mengerjakan soal pada LKS. Setelah mempelajari materi, masing-masing siswa dalam kelompok mengerjakan soal pada LKS. Siswa dalam kelompok berdiskusi untuk memperoleh jawaban yang benar dan memastikan setiap anggota kelompok dapat menyelesaikan atau memahami jawaban kelompoknya. Selain itu, siswa bertanggung jawab baik dalam memahami materi maupun terhadap tugas yang diberikan. Hal ini sesuai dengan pendapat Aprilia (2015) menyatakan bahwa pembelajaran kooperatif tipe NHT membuat siswa akan saling bantu membantu dalam memahami materi yang diberikan. Selanjutnya, siswa mengerjakan tugas mereka masing-masing, siswa bertanya kepada teman atau peneliti ketika mengalami kesulitan dalam mengerjakan tugas dan siswa dalam kelompok lebih aktif dalam belajar serta saling mengajarkan materi maupun hasil pekerjaan tugas yang diberikan. Dalam fase ini, peneliti membimbing dan mengontrol kerja siswa dalam kelompok dan mengarahkan siswa yang mengalami kesulitan. Hal ini sesuai dengan pendapat Kusuma (2008) menyatakan bahwa dalam model NHT peneliti bertindak sebagai motivator, fasilitator, dan kontrol.

Fase menjawab, peneliti bersama siswa melakukan pengundian nomor dan kelompok untuk menetukan siswa yang maju mempresentasikan hasil kerja kelompoknya. Selanjutnya, peneliti memanggil siswa yang diperoleh dari hasil pengundian untuk presentasi di depan kelas. Setelah presentasi, siswa yang bernomor sama diminta untuk menanggapi jawaban yang telah dipresentasikan. Hal ini sejalan dengan pendapat Rafiqa (2014) menyatakan bahwa model pembelajaran kooperatif tipe NHT dapat meningkatkan rasa percaya diri siswa di dalam kelas. 
Memberi pengakuan atau penghargaan, peneliti memberikan penghargaan berupa tepuk tangan kepada siswa yang telah mempresentasikan jawabannya dengan baik. Hal ini sesuai dengan pendapat A Andriani (2016) bahwa pemberian penghargaan bertujuan siswa lebih aktif dan termotivasi untuk berlomba-lomba menjadi kelompok yang terbaik. Peneliti juga mengapresiasikan kelompok yang paling aktif dan semangat seperti yang dijanjikan oleh guru matematika bahwa akan mendapatkan tambahan nilai pada ujian med semester nanti. Hal ini sesuai dengan pendapat Sugiawan (2014) menyatakan bahwa pemberian penghargaan dapat memotivasi seluruh siswa untuk belajar lebih giat lagi.

Hasil tes akhir tindakan siklus I diperoleh bahwa 12 siswa yang memperoleh nilai lebih atau sama dengan 75 dengan presentase ketuntasan klasikal sebesar 34,28 \% menunjukan bahwa siswa masih kurang memahami materi menyelesaikan persamaan kuadrat dengan cara pemfaktoran. Sedangkan hasil tes akhir tindakan siklus II diperoleh bahwa 26 siswa yang memperoleh nilai lebih atau sama dengan 75 dengan presentase ketuntasan klasikal sebesar $74,28 \%$ menunjukan bahwa siswa telah mengalami peningkatan dengan memahami materi menyelesaikan persamaan kuadrat dengan cara melengkapkan bentuk kuadrat sempurna.

\section{KESIMPULAN}

Berdasarkan hasil penelitian dan pembahasan dapat disimpulkan bahwa penerapan model pembelajaran kooperatif tipe NHT yang dapat meningkatkan hasil belajar siswa pada materi persamaan kuadrat di kelas X IPA A SMA Negeri 1 Ampibabo, dengan mengikuti fase-fase sebagai berikut: 1) Penomoran, 2) Mengajukan pertanyaan atau permasalahan, 3) Berpikir bersama, dan 4) Menjawab.

Fase penomoran, Siswa digabung dalam kemampuan yang heterogen pada setiap kelompok dengan tujuan agar siswa yang mengerjakan bagian soal yang sulit dari undian nomor tersebut dapat dibantu oleh siswa yang berkemampuan tinggi, terdapat juga rasa bertanggung jawab dan kerjasama dalam kelompok terhadap pertanyaan yang diberikan. Fase mengajukan pertanyaan atau permasalahan, peneliti membagikan LKS pada masing-masing kelompok dengan tujuan untuk mengetahui penguasaan siswa terhadap materi yang diberikan. Fase berpikir bersama, siswa mengerjakan pertanyaan yang termuat dalam LKS, berdiskusi dalam kelompok untuk memperoleh jawaban yang benar dan memastikan setiap anggota kelompok menyelesaikan dan memahami pertanyaan yang diberikan dengan tujuan agar siswa lebih bertanggungjawab terhadap tugas yang diberikan, hilangnya rasa kesejangan antara siswa yang berpengatahuan tinggi, sedang, dan rendah, adanya rasa ingin tahu dan adanya rasa percaya diri, dan juga semua siswa dapat berperan penting dalam kelompok. Fase menjawab, dilakukan pengundian untuk menentukan siswa yang akan maju mempresentasikan hasil kerja kelompoknya dengan tujuan untuk mengetahui jawaban pertanyaan yang termuat dalam LKS dengan benar, siswa berani dan mampu menjelaskan jawabannya sendiri dan rasa percaya diri siswa meningkat, dan adanya antusias siwa dalam mengerjakan jawaban mereka di depan kelas.

\section{SARAN}

Berdasarkan kesimpulan tersebut, peneliti dapat memberikan beberapa saran yaitu model pembelajaran kooperatif tipe NHT dapat menjadi bahan pertimbangan guru khususnya sebagai alternatif dalam meningkatkan hasil belajar siswa. Namun, guru harus mengefisienkan waktu yang digunakan selama proses pembelajaran berlangsung. Bagi peneliti berikutnya agar dapat 
mencoba menerapkan model pembelajaran kooperatif tipe NHT pada materi yang lain dan memberi sedikit modifikasi pada penerapan agar siswa lebih tertarik untuk belajar.

\section{DAFTAR PUSTAKA}

A. Andriani. Rochaminah, S. Dan Bennu, S. (2016). Penerapan Model Pembelajaran Kooperatif Tipe NHT untuk Meningkatkan Hasil Belajar Siswa pada Materi Penjumlahan dan Pengurangan Pecahan Di Kelas Viismpn Satu Atap Lik Layana Indah. Jurnal Matematika [Online]. Vol 3 (5), 14 Halaman. Tersedia: http:// jurnal.untad.ac.id/ jurnal/ index.php/ AKSIOMA/ article/ view/ 8626. [23 desember 2017]

Aprilia, E. (2015). Perbndingan Kemampuan Representasi Matematis Siswa Dalam Pembelajaran Kooperatif Tipe NHT dan TPS. Jurnal Matematika [Online]. Vol 3 (1), 7 Halaman. Tersedia: http://jurnal.fkip.unila.ac.id/index.php/MTK/article/view/7816/4667. [16 Oktober 2017)

Arikunto, S. (2007). Penelitian Tindakan Kelas. Jakarta: Bumi Aksara

Febriasari, E. (2016). Penerapan Model Pembelajaran Kooperatif Tipe Numbered Heads Together (NHT) Berbantuan Blok Aljabar Untuk Meningkatkan Hasil Belajar Siswa Pada Materi Pemfaktoran Bentuk Aljabar Di Kelas VIII A SMP Negeri 1 Taopa. Skripsi Sarjana FKIP UNTAD. Palu: Tidak Diterbitkan.

Juliah. (2013). Penerapan Model Pembelajaran Kooperatif Tipe Numbered Heads Together (NHT) Untuk Meningkatkan Hasil Belajar Siswa Pada Materi Kuadrat Di Kelas X B MA Negeri Tomini. Skripsi Sarjana FKIP UNTAD. Palu: Tidak Diterbitkan.

Kusuma, E. (2008). Pembelajaran Kooperatif Tipe NHT Berbasis SAVI Untuk Meningkatkan Hasil Belajar Kimia Pokok Bahasan Laju Reaksi. Jurnal Inovasi Pendidikan Kimia [Online]. Vol 2 (01), 8 halaman. Tersedia: http:// journal.unnes.ac.id/ nju /index.php/ JIPK/article/viewFile/1221/1180. [17 Oktober 2017]

Marno dan Idris, M.(2009). Strategi Dan Metode Pengajaran. Jogjakarta: Ar-Ruzz Media.

Paembonan, R. D. Hamid, A. Dan Rochaminah, S. (2014). Penerapan Model Pembelajaran Kooperatif Tipe Numbered Heads Together Untuk Meningkatkan Hasil Belajar Siswa Pada Materi Penarikan Kesimpulan Logika Matematika Di Kelas X SMA GPID Palu. Jurnal Elektronik Pendidikan Matematika Tadulako [Online]. Vol 2 (1), 11 Halaman. Tersedia: http: // jurnal.un-tad.ac.id/ jurnal/ index.php /JEPMT/ article/ view/ 3235/ 2290. [20 januari 2017)

Prawiradilaga, d. S. (2009). Prinsip Desain Pembelajaran. Jakarta: kencana.

Rafiqa, S. (2014). Penerapan Model Pembelajaran Kooperatif Tipe NHT Berbantuan Media Kartu Posinega Untuk Meningkatkan Pemahaman Konsep Penjumlahan Dan Pengurangan Bilangan Bulat Siswa Kelas VII SMP Negeri 15 Palu. Jurnal Elektronik Pendidikan Matematika Tadulako [Online]. Vol 1 (2), 11 halaman. Tersedia: http:// jurnal.untad.ac.id/ jurnal/index.php/JEPMT/article/view/3223. [16 Oktober 2017]

Silalahi, H. (2012). Pengaruh Model Pembelajaran Kooperatif Type NHT (Numbered Heads Together) Terhadap Hasil Belajar Siswa Pada Bidang Studi Matematika Kelas V SD Negeri No. 068003 Medan [Online]. Tersedia: http:// jurnal.unimed.ac.id/ 2012/ index.php/ tematik/article/download/2250/1909. [16 Oktober 2017] 
Sugiawan, R. (2014). Meningkatkan Aktivitas Dan Hasil Belajar Metematika Melalui Pembelajaran Kooperatif Tipe NHT. Jurnal Matematika [Online]. Vol 3 (1), 12 Halaman. Tersedia: http://jurnal.fkip.unila.ac.idindex.php/MTK/article/view/4655/2899. [16 Oktober 2017]

Suhardi, Pasaribu, P. Dan Nuryanti, S. (2014). Penerapan Model Pembelajaran Kooperatif Tipe Numbered Heads Together (NHT) Untuk Meningkatkan Hasil Belajar Siswa Pada Materi Mata Pelajaran IPA Kelas IV SD Negeri 3 Tondo. Elementary School Of Education EJournal [Online]. Vol 2 (2), 8 Halaman. Tersedia: http:// jurnal.untad.ac.id/ jurnal/ index.php/ ESE/article/view/2824. [11januari 2017)

Suprijono, A. (2009). Cooperative Learning Teori Dan Aplikasi PAIKEM. Yogyakarta: Pustaka Belajar.

Wijayanti, W. (2010). Usaha Guru Dalam Meningkatkan Motivasi Belajar Matematika Siswa SMA Negeri 1 Godean. Skripsi FMIPA Universitas Negeri Yogyakarta [Online]. Tersedia http:// eprints.uny.ac.id/ 2265/ 1/ Wahyu_Wijayanti_06301244078.pdf. [15 Oktober 2017] 